\author{
Lidia Marszatek* \\ ORCID: 0000-0002-8425-9591 \\ Płock, Poland
}

\title{
Religious Education of a Child in a Family as Building up Basic Hope
}

\section{Wychowanie religijne dziecka $w$ rodzinie jako budowanie nadziei podstawowej}

\begin{abstract}
Summary: Basic hope is a fundamental component of a human's general scheme or rather related patterns of the real world. Its essence is the conviction of its sense, justice and favour of the world for a person. The aim of the text is to present the meaning of natural religious education in the family for building basic hope in the child's life in the context of his later life-long functioning.
\end{abstract}

Key words: child; religion; family education; religious education; basic hope.

Streszczenie: Nadzieja podstawowa jest fundamentalnym składnikiem posiadanego przez człowieka ogólnego schematu czy też raczej powiązanych schematów rzeczywistego świata. Jej istotą jest przekonanie o jego sensie, sprawiedliwości i przychylności. Celem tekstu jest przedstawienie znaczenia naturalnego wycho-

* Dr hab. Lidia Marszałek - professor of The Mazovian State University in Płock, Faculty of Humanities and Social Sciences, Department of Special Education and Resocialisation. Address: Faculty of Humanities and Social Sciences of The Mazovian State University, ul. Gałczyńskiego 28, 09-400 Płock; email: lidia.marszalek@gmail.com. 
wania religijnego $\mathrm{w}$ rodzinie dla budowania nadziei podstawowej w życiu dziecka w kontekście jego późniejszego całożyciowego funkcjonowania.

Słowa kluczowe: dziecko; religia; wychowanie w rodzinie; wychowanie religijne; nadzieja podstawowa.

\section{The essence of basic hope}

Hope is a driving force for human activity. Even though the objective that an individual is striving for is valuable for him, its attainment is connected with some degree of uncertainty. He can never be sure about the achievement of the intended goal, although he hopes for it and it is indeed this hope that motivates him for taking action. Hope is an indispensable virtue for a man in time of crisis as well as in time of prosperity. Thanks to it, people have a sense and purpose of their own activity 1 . "Hope always relates to some value that we are to reach or even otherwise: to the value that we wish to bring to our life. Therefore, hope voices the primary meaning of our life. This meaning does not depend, most of all, on what we have but on our awareness concerning the value of our humanity, our human dignity." When it comes to the entire human life, a question of hope is simply the ultimate question. It is an openness, availability of an outgoing person involved in the community. Therefore, hope reveals to a man that he is "on the way" to full self-expression".

Questions applying to hope constitute basic questions in the essence of human existence. "A person turned to the future, setting distant and far-reaching goals, searching for the ways leading to the desired outcome and able to - though with mistakes - perform activities, is frequently homo esperans, a man of hope." "It is hope through which a human life makes sense, acquires specific value; nevertheless, the question remains: what will be the direction

${ }^{1}$ Cfr. Jerzy Trzebiński, Mariusz Zięba, “Nadzieja, strata i rozwój”, Psychologia Jakości Życia 1/2 (2003): 6 .

2 Dante Alimenti, Alberto Michelini, Wy jesteście moją nadzieja. Fragmenty przemówień Jana Pawła II do młodzieży 1978-1985, trans. Kazimierz Szczerba (Warszawa: Wydawnictwo Salezjańskie, 1987), 187.

${ }^{3}$ Cfr. Stanisław Chrobak, Podstawy pedagogiki nadziei. Współczesne konteksty w inspiracji personalistyczno-chrześcijańskiej (Warszawa: Wydawnictwo UKSW, 2009), 496.

4 Józef Kozielecki, Psychologia nadziei (Warszawa: Wydawnictwo Akademickie Żak, 2006), 31 . 
of this hope? What do people have in mind when they refer to hope and cherishing hope? Why is it so universal? Why does life deprived of it induce despair?

In accordance with the philosophy of Józef Tischner, hope is "a modulator of sense, «a hermeneutic mediator» between the world of experience, values and what this world becomes for an individual. Within hope a specific sensitivity of human receptivity is developed: readiness and ability to recognise the fields in relation to which values serve as the basic principle of their meaning." 5 The author understands the concept of hope in the manner specified by Józef Kozielecki and Józef Tischner.

On the other hand, basic hope is a scientific term taken from the idea of psychosocial development created by Erik Erikson ${ }^{6}$. This author anticipated the possibility of human development for the rest of one's life. He distinguished eight stages throughout the human life cycle in which an individual is faced with a different conflict or crisis linked to the emergence of new needs, skills or tasks imposed by society which have to be resolved so that he can achieve a higher stage of development. Overcoming a crisis enriches the human ego with new dispositions. At the other end of the spectrum, a wrong solution to the dilemma or lack of its solution is always unfavourable to a person since it weakens his ego and leads, in some cases, even to pathology?

Hope is synonymous with "stimulation", both internally and externally as well as individual and social ones. Childhood experiences play a significant role in human development but they do not remain invariable. In each period of development, there is a possibility of change that could solve the problems deriving from earlier periods. Man is the creator of his own life and he makes it unique. Development is the process of achieving an increasing coherence of ego, a sense of identity. Hope is associated with openness to new experiences and it is conducive to the formation of positive attitudes towards novelty ${ }^{8}$.

${ }^{5}$ Cfr. Józef Tischner, Świat ludzkiej nadziei (Kraków: Znak, 1975), 296.

${ }^{6}$ Magdalena Sękowska, "Neopsychoanalityczna koncepcja rozwoju psychospołecznego Erika H. Eriksona”, in: Duchowy rozwój człowieka: fazy życia, osobowość, wiara, religijność. Stadialne koncepcje rozwoju w ciagu życia, ed. Paweł Socha (Kraków: Wydawnictwo UJ, 2000), 110.

7 Ibidem, 260; cfr. Maria Jankowska, "Nadzieja człowieka w aspekcie wiary i rozumu”, in: Czy rozum jest w konflikcie z wiara? $W$ X rocznice ogłoszenia Encykliki Fides et Ratio, eds. Jan Krokos, Maria Ryś (Warszawa: Wydawnictwo UKSW, 2009), 215-230.

${ }^{8}$ Cfr. Chrobak, Podstawy, 74. 
A man is able to act as long as he sees what is ahead of him. Where hope is removed, a man ceases to exist. Each development consists of many painful and joyful memories which are accompanied by hope of achieving a variety of higher forms 9 .

Erik Erikson maintained that there is a fundamental virtue of ego which, in his concept, denoted a life force being the result of a successful resolution of crises belonging to a given developmental stage. According to him, hope is the first, basic and the strongest virtue that comes into being. Basic hope is the earliest virtue which, adequately shaped throughout infancy, becomes the start of the faith of a person. Together with consecutively acquired competences of ego, it contributes in shaping one's identity, and subsequently, in close and lasting ties full of love with other people. In a twilight of one's life, basic hope, in the light of fides and ratio, does not allow an individual to succumb, up against transience, to a state of despair and makes it possible to achieve the coherence of ego, and also the virtue of wisdom. Indeed, all the virtues are interrelated and they do not exist separately; moreover, it is nothing but hope that makes their lifelong development feasible ${ }^{10}$. Hence, basic hope is an essential component of a general pattern held by an individual or rather of associated patterns of a real world. "These cognitive patterns present the real universe, in which all the past, current and future also existed, likely and possible (alternative) events take place." ${ }^{11}$ People's convictions, constituting their basic hope, cover places of events they experience or about which - at a later stage - they know from others. This world for a child is his immediate family, both in the sense of a space as well as specific relationships and episodes between his family members ${ }^{12}$.

Basic trust (hope) is formed from the moment of the birth of a child up to the age of two. At that time, specific physical experiences connected with mother-infant contact start to assert: repetitive actions of feeding and washing, the warmth of physical contact with a mother, her constant presence, harmony, consistency and identical experiences. In this manner, a child becomes convinced step by step that the surrounding world is a friendly, predictable

${ }^{9}$ Cfr. ibidem, 116.

${ }^{10}$ Cfr. Jankowska, "Nadzieja”, 215-230; Paweł Socha, “Teolog jako psycholog: koncepcja rozwoju wiary Jamesa W. Fowlera”, in: Duchowy rozwój człowieka. Fazy życia, osobowość, wiara, religijność, ed. Paweł Socha (Kraków: Wyd. UJ, 2000), 170; Sękowska, "Neopsychoanalityczna", 138.

11 Trzebiński, Zięba, "Nadzieja", 7.

${ }^{12}$ Cfr. ibidem, 8. 
and thus reliable place ${ }^{13}$. If a basic trust in this early stage of life prevails, a child learns to rely on himself, perceive himself as a trustworthy person and cope with his own impulses ${ }^{14}$. On the other hand, a lack of child's basic needs, lack of unity with mother and bad childcare may lead to the preservation of a child's basic distrust which, in turn, might have a major impact on his subsequent life ${ }^{15}$.

Erikson perceives basic hope as the first achievement of a child's mind (ratio) towards the formation of his ego and furthermore, as an integration of a basic trust and distrust, but with a predominance of the first one. Therefore, basic hope is a conviction, emerged from a baby's first contact with mother still in a preverbal stage of life, about some constant features of the world: a universal order and favourability towards people, which gives cause to believe in a well-ordered and safe, though dynamic, process of ego development ${ }^{16}$.

According to Erikson's theory, hope is a certain conviction of an individual about interrelated features of the world: that it is well-ordered, purposeful and generally favourable towards people. These are beliefs concerning the higher order and the good of the world which are the bones for the interpretation of events happening in the world, and which allow an individual to assess and evaluate one's chances within it. Hope is an essential competence of ego enabling a person to respond constructively to two situations: a novelty and a breakdown of a former order. Basic hope gives a person a will and a conviction necessary for taking the fight for what he lost.

Thus, the content of basic hope constitutes three assumptions. The first one is the conviction of an order and purposefulness of the world. A small child experiences this conviction in a non-rational, intuitive way through a personal experience of some phenomena and through expectations of a concrete fact when the other fact occurred. In subsequent stages of development, expectation of an order is a conviction concerning the existence of regularities not necessarily known by an individual, but regularities which are universal, that is to say they do not concern only his own affairs. Except for the convictions of regularity adaptable to causal relationships, there is a conviction of purposefulness of phenomena happening in the surrounding reality and, as

${ }^{13}$ Erik Erikson, Dzieciństwo i społeczeństwo, trans. Przemysław Hejmej (Poznań: Rebis, 2000), 257-261.

${ }^{14}$ Cfr. Jankowska, "Nadzieja”, 220; Erikson, Dzieciństwo, 259.

15 Erikson, Dzieciństwo, 258.

16 Cfr. Jankowska, "Nadzieja", 221. 
a consequence, of the sense and purposefulness of the world as a whole. The conviction of purposefulness of the world is a conviction that the world has a sense and facts happening within it come into prominence on the grounds of this sense.

The other assumption of basic hope is the conviction that the world is favourable towards people. From the perspective of a small child, the favourability of the world means that his needs are satisfied and the communication of his own need is noticeable by others. During the development process, the meaning of this favourability moves away from a child's egoism and undergoes a process of generalisation. It is hope and faith in the fact that one can generally meet a larger number of good events than bad ones in the world and that ultimately, he can always count on the support of others.

The third belief, shaped in the course of building basic hope, is justice of the world. This signifies the faith in the fact that our activities and "merits" in the favourable world are awarded, and, on the other side, our abandonments and wrongdoing get us farther from rewards or straightforwardly carry the penalty. The nature of this faith consists in the conviction that "people get from the world what they deserve. The world order indicated in this principle shall ensure the association of good which an individual receives in this world from what he does and «what he is worth»"17.

The beginnings of hope arise during the first meeting of a new-born child with his parents who inspire his confidence, fulfil his need for acceptance and for entry into the environment. Thanks to an increasing number of experiences in which a new-born's hope is confirmed, he receives an inspiration for new hope. Simultaneously, an ability to both reject unfulfilled hopes and look for hope in future goals and plans is developed ${ }^{18}$. In a family, which is a child's initial model of the world, there are various forms of upbringing and various family situations; therefore, people differ from each other in a degree of intensification of basic hope. Rational building of a child's conviction about an order and sense of the world is created through regularity, continuity and predictability of a mother's caring activities as well as through close, trustful relationship with her. This fact encompasses not only phenomena directly linked to a child, but also phenomena which do not concern him, or which he cannot even understand or observe, but he is convinced that they exist. Additionally, if the world as a whole has a sense for a child, all particu-

\footnotetext{
17 Trzebiński, Zięba, "Nadzieja", 8-9.

${ }^{18}$ Cfr. Chrobak, Podstawy.
} 
lar and individual incidents occurring within it gain an importance and make sense for him ${ }^{19}$.

Basic hope is a relatively stable personality structure which is not subject to such changes like opinions and attitudes formed at a later stage. It is deeply rooted in a human being's mind. It is disclosed in a way of interpreting future and current experiences as well as of predictions of future events. Thus, basic hope is shaped as a result of actions taken by a supportive family and reveals itself in the way of interpreting past and present experiences and predicting future events.

Basic hope is not the same as excessive optimism, one's naivety or its colloquial term "the mother of fools". Thus, high level of basic hope does not exclude misfortune, pointlessness or doubts in a person's life, but they relate only to specific situations, moments and choices. Strong belief in an order, sensibleness and favourability of the world makes it easier to resign oneself to irreversible loss and proceed to the building of a new order. This belief also increases openness to new experiences, acceptance of challenges as well as the use of social support and the assistance of others in difficult moments of life ${ }^{20}$. The regulatory role of basic hope consists in a constructive dealing with difficult situations which, in this manner, become developing situations.

The power of basic hope in our life shall be revealed in cases of critical, ground-breaking situations which destroy the lasting order and threaten our self-esteem or realisation of significant life goals. It determines, then, whether we feel only threatened, helpless, apathetic or we accept challenges coming from particular situations ${ }^{21}$.

Problems of a person faced with a loss, new situation in life or a challenge might be described in the following way: is it possible and is it worth it to search for a new order which will replace the destroyed one and will make sense of an important aspect of life or - at times - of the whole life? A key factor determining the way of conduct in this situation are one's convictions about the world in which he can find the order or not. If the world includes factors enabling to reach this order, a person will make an attempt to explore it with a greater conviction. When an individual has got a strong hope in the sensibleness and

${ }^{19}$ Cfr. Stanisław Głaz, Krzysztof Grzeszek, Iwona Wiśniewska, Rodzina: biologiczne i psychiczne podstawy jej funkcjonowania (Kraków: Wydział Filozoficzny Towarzystwa Jezusowego, 1996); Trzebiński, Zięba, "Nadzieja”, 8.

${ }^{20}$ Trzebiński, Zięba, "Nadzieja”, 10-14.

${ }^{21}$ Cfr. ibidem, 10-11. 
favourability of the world, he will look for a new order and will accept the loss of the old one more quickly ${ }^{22}$.

Thanks to hope, it is possible to get the idea of a mysterious sense of various incidents, human decisions and dramas. "Hope keeps speaking to us, even when we succumb entirely to desperation; it encourages us to rethink ambiguity and uncertainty manifested in history; it tells us: find a meaning for your life, try to understand it." ${ }^{23}$

\section{Basic principles of religious development in a child}

Józef Wilk described the process of religious education in three stages. The first stage is called the phase of awakening. From the very first moments of a baby's life, parents contact with him by feeding, touch, talking etc. Father and mother become a child's "bridge" to God. The next step is the phase of development, in which religious education consists in sensitizing a child to a deeper sense of the surrounding world and searching for God within it. According to Józef Wilk, the third phase of religious development in a child is the phase of complement. This stage is associated with a complete religious education. It is vital here that a child does not participate only passively in religious practices, but he also expresses his faith actively. At this stage of development, the deepest confession of child's faith is his individual "conversation with God", so a prayer ${ }^{24}$.

A child can engage in a living and dynamic relationship with God very early. C. Walesa divides the beginnings of religiousness of a child into two phases: religiousness "following his mother" in the second year of life and the beginnings of individual religiousness in the third year of life. In the first stage, a child follows and repeats short prayers after adults. Through the phenomenon of "initial confidence" (basic hope), awoken by experiencing parent's love, a child is located in a symbiotic unity with the environment, being simultaneously included in the spiritual life his of parents ${ }^{25}$. A three-year-old-

${ }^{22}$ Cfr. ibidem, 12-13.

${ }^{23}$ Paul Ricoeur, Podtug nadziei. Odczyty, szkice, studia, ed. Stanisław Cichowicz (Warszawa: Instytut Wydawniczy Pax, 1991), 195.

${ }^{24}$ Cfr. Józef Wilk, Pedagogika rodziny. Zagadnienia wybrane (Lublin: Poligrafia Salezjańska, 2002), 127-136.

${ }^{25}$ Cfr. Adam Solak, Człowiek i jego wychowywanie (Tarnów: Academica, 2004), 71-72. 
child may get a partial idea of religion. A child begins to be aware of the intimacy and individual character of religious acts, particularly a prayer. He is also able to turn to God spontaneously, to ask, thank, apologise and worship God; he starts to ask questions concerning religious issues. These are still parents and people from his immediate environment who have the greatest impact on shaping his attitudes, and the main mechanism of shaping them is imitation.

Four-year-old and five-year-old children, in turn, understand the reality in an unrealistic way - their reasoning intermingle everyday life with fantasy. Many researchers claim that they attribute the features of a magician to God and magical power to a prayer. By way of a prayer and "good conduct", children attempt to put pressure on God's decisions ${ }^{26}$. They perceive him as the immortal, omniscient, omnipotent Creator and Giver of everything, and the characteristic feature of this perception is anthropomorphism. A prayer is formulated in a personalistic way - a child "speaks to God" as if he spoke with all the other creatures, even with toys, treating them as partners. This feature makes that a child's contact and "conversation" with God who cannot be seen is much easier. A child's family, and particularly his parents, is the first environment of religious experiences for him. Therefore, the issue of religious education indicates that family environment has fundamental importance in this process; it is precisely family from which the real roots of one's faith begin to sprout. The objective of parents' actions is not so much knowledge, getting to know God and understanding him, but their love for him and neighbours expressed in emotions, intentions, pursuits and practices.

In religiousness of a small child, it is hard to isolate his own contribution from skills achieved by means of mechanical imitation of adults. It is true, however, that he usually adopts patterns of religious behaviours from a person from whom he experiences the greatest sense of security. Furthermore, these are usually parents. Over time, a child's experiences become richer and deeper - he becomes increasingly aware of the fact that parents are not always in a position to satisfy all his needs, even the right ones, and he repeatedly witnesses the situation in which they entrust God with various difficult affairs. That way, a child begins to place his confidence in someone who gained the trust of his parents ${ }^{27}$. Children's Credo becomes the conviction that "God

${ }^{26}$ Cfr. Stanisław Kuczkowski, Psychologia religii (Kraków: WAM, 1998), 71.

${ }^{27}$ Cfr. Jan Szpet, "Rozwój pojęć religijnych u pięcioletniego dziecka", in: Katecheza, rodzina, parafia, szkoła, vol. 5: Katecheza w przedszkolu, eds. Jan Szpet, Danuta Jackowiak (Poznań: Wyd. UAM, 2007), 31. 
can do anything". God is someone from whom they can expect everything, even the impossible. During that period a child has absolute trust in God - he should come to his assistance and take control over the most difficult problems of existence.

\section{Tasks of (future) parents - examples of practical actions}

Parents are the first and the most important teachers of love, its givers and receivers. It is from them that a child learns how to show his love and express his emotions. Family members are a system of reference, a source of activity and behavioural patterns or transmitters of patterns and models of conduct, and the emotional proximity creates especially favourable conditions for mental transmission, so the exchange and undertaking of relatives' experiences $^{28}$. The awareness of affectional bonds with relatives gathers the "capital of warmth" in a child's heart for the whole life. In this context, Erich Fromm uses a very wise metaphor of milk and honey. While milk symbolises everything that a man needs for satisfying his simple necessities of life, honey is the equivalent of happiness. In Fromm's view, it is very easy to distinguish people who received only "milk" from those who mixed "milk" with "honey". Those who were not loved properly in childhood might experience then low self-esteem, loneliness and rejection ${ }^{29}$. The more secure a child is in satisfying all his needs by the immediate environment, the more rapidly and fully the sense of emotional stability develops and extends within him.

Meeting the primary need of a child - the need for charity - paves the way for shaping a child's religiousness and basic hope. "For every person, charity received and given is the primordial experience which gives rise to hope" ${ }^{30}$. Many researchers of the relationships between parents and children note that parents, within the meaning of a child, have the preeminent "psycho-

${ }^{28}$ Maria Tyszkowa, “Jednostka a rodzina: interakcje, stosunki, rozwój”, in: Psychologia rozwoju człowieka, vol. 1: Zagadnienia ogólne, eds. Maria Przetacznik-Gierowska, Maria Tyszkowa (Warszawa: PWN, 2005), 126.

${ }^{29}$ Cfr. Erich Fromm, O sztuce miłości, trans. Aleksander Bogdański (Warszawa: Rebis, 2006), 63 .

30 Jan Paweł II, "Adhortacja apostolska Ecclesia in Europa", in: Adhortacje apostolskie Ojca Świętego Jana Pawła II (Kraków: Znak, 1997), n. 84. 
logical significance" - they are initially treated as a kind of deity, all-knowing and all-powerful person ${ }^{31}$.

Growing up in a religious environment, a child absorbs the customs, rituals, habits and religious practices just "on a mother's lap", and their specificity of a simple entrustment to God and straightforwardness is particularly suitable for a child's nature - perception of the material and immaterial world as components of the same reality. Parents and their example of life are the most significant methods of religious education, no other way is able to substitute a personal, educational relationship with a child - it shall only support it. As far as the upbringing of a child is concerned, words are not so much important as an example of life, fostering traditions and values. This process, thanks to personal contacts characterised by genuine love, should occur in a climate of family's trust, frankness, straightforwardness, simplicity, kindness, respect and satisfaction of child's needs.

A child wishes to be loved and accepted; he needs and seeks warmth and appreciation. Thereby, he forges a bond with his parents and strengthens the dialogue expressed by love and affection. A child is in need of infinite and total love. Parents' love - provided that there is - is absolute, total, unconditional, at times "contrary to" the facts and situations - not only when a child is kind and obedient, but also when he is angry, fussy or prankish, when he makes mistakes and suffers defeats of his life. The more a child is certain of his needs being fed by the immediate environment, the sooner the sense of emotional stability thrives and expands in him. With the aid of parental influence, the world of a child is seen by him as well-ordered, meaningful, just and well-affected.

Meeting the fundamental need of a child - being loved by the nurturing love and having someone to love - is also a basis for shaping religiousness of a child. This is because children see their parents not only as people older and stronger, but also as people smarter than they are. It seems for a small child that there is nothing that parents may not know and there is nothing they could not do. In this dialogic meeting with parents, a child takes words and deeds of adults personally and experiences them as his own ones - an adult is an authority and exemplar for him. For a child, the relationship with his parents is a "prototype" of all the relationships forged in the material

31 Przemysław Jabłoński, "Duchowy rozwój człowieka jako rozwój rozumienia języka religijnego", in: Duchowy rozwój człowieka. Fazy życia, osobowość, wiara, religijność, ed. Paweł Socha (Kraków: Wyd. UJ, 2000), 199. 
and transcendent world. Confidence, calmness and primarily unconditional love of parents allow a child to reinforce the conviction that God, to whom parents entrust with a prayer, is similar to them, is characterised by the same features and experiences the same feelings in relation to the child. This way, "husband and wife, father and mother, both "cooperate with the love of God the Creator, and are, in a certain sense, his interpreters». They show their children the maternal and paternal face of the Lord" ${ }^{\prime 2}$.

A child wishes to ask trustfully for everything he needs; he wants to be sure that apart from his parents, there is God from whom everything comes and who, despite his mistakes and weaknesses, loves him for what he is and partakes in his joys and worries. "A child knows that there is someone who loves him very much and who takes care of him"33. Divine love, seen through adult's eyes, is something that he, in a certain way, has to earn by his own conduct. God viewed from the perspective of an adult is a judge; God seen with child's eyes - a loving father ${ }^{34}$. The reason for this is that a child, in his emotionality, is particularly sensitive to the signs of love, and he builds the image of God in the light of his relationship with another person. God, from the standpoint of a child, is God of love which he notices in his life and which he can truly rejoice in.

Religious initiation thus has a character of natural socialisation inserted in the entire educational process, while a child himself, permanently and dynamically turned towards God, is able to experience transcendence and strive consciously for the ultimate goal - forming his personality in the image and likeness of God.

Religious sphere cannot be separated from everyday life and experiences related to it as well as from education since their relationship is indissoluble. The initial step in forming a child's character is to teach him to distinguish between evil and good as well as to make him realise the implications of the choice of values. Therefore, the task of parents is to protect their children from evil influences, build the basis of axiology and develop the abilities of making the way into good in conjunction with customs and morality of the

${ }^{32}$ Franciszek, Adhortacja Amoris Laetitia (Kraków: WAM, 2016), n. 172.

${ }^{33}$ Maria Montessori, as cited in: Pedagogika Marii Montessori w Polsce i na świecie, ed. Barbara Surma (Łódź-Kraków: Pallatum, Ignatianum, 2009), 44.

${ }^{34}$ Francesca Cocchini, "Możliwości religijne dziecka", trans. Barbara Surma, in: Pedagogika Marii Montessori w Polsce i na świecie, ed. Barbara Surma (Łódź-Kraków: Pallatum, Ignatianum, 2009), 209. 
family community ${ }^{35}$. Parents are responsible for satisfying their child's needs, but they also constitute his mental and physical context of the world. Their reactions to the child's behaviour contain elements of evaluation, thanks to which they convey the meanings of his conduct and the relations between people and the whole world.

Due to the fact that adults have considerable standing, a child assumes that he should implicitly undertake their orders. At that time, the motivation of behaviour has egocentric character which should not be, however, subject to assessment in terms of good and evil, since at that age, it is the manifestation of child's developmental features. Even though moral experiences (in adults' estimation - simplified and trivial) appear to be a projection or reflection of judgements functioning within a child's environment, they bear the stamps of moral and aesthetic evaluation for himself. The salience of these assessments is only important for moral development insofar as they are many times uniquely constant. Besides, in later periods of life they become fundamental to the formation of emotional attitude towards specific facts which is precisely based on basic hope shaped in the early period. The research of Jerzy Trzebiński and Mariusz Zięba proves that stronger hope diminishes the intensity of personality factors in adjustment disorders like anxiety and depression as well as it reduces the occurrence of somatic manifestations of the disorders. On the other hand, stronger hope augments the intensity of pro-development factors, such as optimism, well-being, self-confidence and confidence in one's own success, and what is more, a significant factor in building one's hope might be contact with a person who, with his behaviour and emotions, changes confidence into the favourability of the world ${ }^{36}$. For a child, a primary model for identification and shaping behaviours are members of his family a mother and a father. Their behaviours towards a child determine satisfaction of both his justified needs and his acquisition of the certainty that the world is well-ordered, sensible and favourable. "In a relationship of people, hope is a belief in goodness of another person and in 'tomorrow' of this goodness - in the development and sense of this development" ${ }^{37}$.

Nevertheless, contemporary young parents are sometimes not fully aware of how their early, unconscious upbringing of a child is important for not only the formation of subsequent attitude towards faith and religion, but also for

\footnotetext{
${ }^{35}$ Cfr. Franciszek, Amoris Laetitia, n. 264.

36 Trzebiński, Zięba, "Nadzieja", 29-30.

${ }^{37}$ Chrobak, Podstawy.
} 
building the grounds for "initial confidence", so basic hope. They repeatedly claim that regular fulfilment of religious practices (Sunday Mass, sacraments, family traditions and religious customs) is a sufficient condition for a correct religious formation of their child. A special role, therefore, in the field of building knowledge and awareness among young parents - apart from strictly pedagogical education - might be played, and should be played, by the pastoral care of engaged and married couples.

This involves not only helping them to accept the Church's teaching and to have recourse to her valuable resources, but also offering practical programmes, sound advice, proven strategies and psychological guidance. All this calls for a pedagogy of love, attuned to the feelings and needs of young people and capable of helping them to grow interiorly ${ }^{38}$.

They should thus serve not only for religious formation of married couples and building their mutual bond, but also for indicating a significant role of their mutual love for the process of a child's early religious education and in this way, "furnish" him with hope for the rest of his life.

In the content of this research and practical advice, one should find elements of developmental psychology of a child, basic knowledge about correctness and determinants of education process, especially in early childhood. Furthermore, this knowledge should directly indicate to the particular importance of mechanism of formation and identification as well as emphasise the role of parents and their relationship with a child as a prototype of his future relationships with God and other people. It implies the necessity of inviting pedagogues and psychologists, especially those specialising in the development and upbringing of a small child, but also those having concurrently knowledge and competence in a lifelong learning, to participate in those meetings and lectures. Thereby, they would be able, transmitting knowledge about the process of early upbringing of a child, to select suitable methodology of educational work with adults. It would also be vital to plan the time in which this education would encompass young or future parents. "Postponement" of these influences to a later period, when a child is catechised (most commonly about the age of five or six) and his parents are involved in the process of his institutional education, carries the risk of an abandonment of crucial actions in a child's early religious education and "the forfeiting" of a particular chance to affect his natural religious development.

${ }^{38}$ Franciszek, Amoris Laetitia, n. 211. 
The original, non-verbal dialogue between parents and a child, surrounding him with love and shaping relationships based on primal trust ${ }^{39}$, constitute a condition to develop a child's sensible tendency toward religiousness, trust in God and building hope in exploring the meaning of his own life.

\section{References}

Alimenti, Dante, Alberto Michelini. Wy jesteście moja nadzieją. Fragmenty przemówień Jana Pawła II do młodzieży 1978-1985, trans. Kazimierz Szczerba. Warszawa: Wydawnictwo Salezjańskie, 1987.

Chrobak, Stanisław. Podstawy pedagogiki nadziei. Wspótczesne konteksty w inspiracji personalistyczno-chrześcijańskiej. Warszawa: Uniwersytet Kardynała Stefana Wyszyńskiego, 2009.

Cocchini, Francesca. "Możliwości religijne dziecka", trans. Barbara Surma. In: Pedagogika Marii Montessori w Polsce i na świecie, ed. Barbara Surma, 207-212. Łódź-Kraków: Pallatum-Ignatianum, 2009.

Erikson, Erik. Dzieciństwo i społeczeństwo, trans. Przemysław Hejmej. Poznań: Rebis, 2000.

Franciszek. Adhortacja Amoris Laetitia. Kraków: WAM, 2016.

Fromm, Erich. O sztuce miłości, trans. Aleksander Bogdański. Warszawa: Rebis, 2006.

Głaz, Stanisław, Krzysztof Grzeszek, Iwona Wiśniewska. Rodzina: biologiczne i psychiczne podstawy jej funkcjonowania. Kraków: Wydział Filozoficzny Towarzystwa Jezusowego, 1996.

Jabłoński, Przemysław. "Duchowy rozwój człowieka jako rozwój rozumienia języka religijnego". In: Duchowy rozwój człowieka. Fazy życia, osobowość, wiara, religijność, ed. Paweł Socha. Kraków: Wyd. UJ, 2000.

Jan Paweł II. "Adhortacja apostolska Ecclesia in Europa". In: Adhortacje apostolskie Ojca Świętego Jana Pawła II. Kraków: Znak, 1997.

Jankowska, Maria. "Nadzieja człowieka w aspekcie wiary i rozumu". In: Czy rozum jest $w$ konflikcie z wiara? W X rocznice ogłoszenia Encykliki Fides et Ratio, eds. Jan Krokos, Maria Ryś, 215-230. Warszawa: Wyd. UKSW, 2009.

Kozielecki, Józef. Psychologia nadziei. Warszawa: Wydawnictwo Akademickie Żak, 2006.

Kuczkowski, Stanisław. Psychologia religii. Kraków: WAM, 1998.

${ }^{39}$ Cfr. Wilk, Pedagogika, 127. 
Pedagogika Marii Montessori w Polsce i na świecie, ed. Barbara Surma. Łódź: Wyd. Pallatum, Kraków: Ignatianum, 2009.

Ricoeur, Paul. Podtug nadziei. Odczyty, szkice, studia, ed. Stanisław Cichowicz. Warszawa: Instytut Wydawniczy Pax, 1991.

Sękowska, Magdalena. "Neopsychoanalityczna koncepcja rozwoju psychospołecznego Erika H. Eriksona". In: Duchowy rozwój człowieka: fazy życia, osobowość, wiara, religijność. Stadialne koncepcje rozwoju w ciagu życia, ed. Paweł Socha. Kraków: Wydawnictwo Uniwersytetu Jagiellońskiego, 2000.

Socha, Paweł. "Teolog jako psycholog: koncepcja rozwoju wiary Jamesa W. Fowlera”. In: Duchowy rozwój człowieka. Fazy życia, osobowość, wiara, religijność, ed. Paweł Socha, 165-189. Kraków: Wyd. UJ, 2000.

Solak, Adam. Człowiek i jego wychowywanie. Tarnów: Academica, 2004.

Szpet, Jan. "Rozwój pojęć religijnych u pięcioletniego dziecka". In: Katecheza, rodzina, parafia, szkoła, vol. 5: Katecheza w przedszkolu, eds. Jan Szpet, Danuta Jackowiak. Poznań: Wydawnictwo Uniwersytetu Adama Mickiewicza, 2007.

Tischner, Józef. Świat ludzkiej nadziei. Kraków: Znak, 1975.

Trzebiński, Jerzy, Mariusz Zięba. "Nadzieja, strata i rozwój”. Psychologia Jakości Życia 1/2 (2003): 5-33.

Tyszkowa, Maria. “Jednostka a rodzina: interakcje, stosunki, rozwój”. In: Psychologia rozwoju człowieka, vol. 1: Zagadnienia ogólne, ed. Maria Przetacznik-Gierowska, Maria Tyszkowa, 124-150. Warszawa: PWN, 2005.

Wilk, Józef. Pedagogika rodziny. Lublin: Poligrafia Salezjańska, 2002. 